\title{
ON NECESSARY AND SUFFICIENT CONDITIONS FOR VALIDITY OF SOME CHEBYSHEV-TYPE INEQUALITIES
}

\section{ANDRIY L. SHIDLICH}

Abstract. We obtain necessary and sufficient conditions for validity of some Chebyshev-Type inequalities.

Mathematics subject classification (2010): 26D15.

Keywords and phrases: Inequalities, Chebyshev's inequality, monotone functions.

\section{REFERENCES}

[1] D. S. Mitrinović, J. E. PeČArić, A. M. Fink, Classical and new inequalities in analysis, Kluwer (1993), $740 \mathrm{p}$.

[2] P. L. Cheb y henev, O priblizhennyh vyrazhenijah odnih integralov cherez drugie, Soobschenija i Protokoly Zasedanij Matematicheskogo Obschestva pri Imperatorskom Khar'kovskom Universitete, 2 (1882), 93-98; Polnoe Sobranie Sochinenii P. L. Chebysheva. Moskva-Leningrad, 1978, 3, 128-131.

[3] P. L. CheB yshev, Ob odnom rjade, dostavljajuschem predel'nye velichiny integralov pri razlozhenii podintegral'noi funkcii na mnozhiteli, Prilozhenie k 57 tomy Zapisok Imp. Akad. Nauk, 4 (1883); Polnoe Sobranie Sochinenii P. L. Chebysheva. Moskva-Leningrad, 1978. 3, 157-169.

[4] K. A. Possè, $O$ dopolnitel'nom chlene v formule P.L. Chebysheva dlja priblizhennogo vyrazhenija odnogo opredelennogo integrala cherez drugije, vzjatyje v teh zhe predelah, Soobschenija i Protokoly Zasedanij Matematicheskogo Obschestva pri Imperatorskom Khar'kovskom Universitete, 1 (1883), $5-17$.

[5] K. A. Andreief, Neskol'ko slov po povodu teorem P.L. Chebysheva i V.G. Imshenetskogo ob opredelennyh integralah or proizvedenija funcij, Soobschenija Khar'kovskogo Matematicheskogo Obschestva pri Imperatorskom Khar'kovskom Universitete, 1883, 110-123.

[6] N. JA. Sonin, O nekotoryh neravenstvah otnosjascihsja k opredelennym integralam, Zap. Imp. Akad. Nauk po Fiziko-matem. Otd., 6 (1898), 1-54.

[7] D. S. Mitrinović AND P. M. VAsiĆ, History, variations and generalisations of the Čebyšev inequality and the question of some priorities, Univ. Beograd. Publ. Elektrotehn. Fak. Ser. Mat. Fiz., 461-497 (1974), 1-30.

[8] D. S. MitrinoviĆ AND J. E. PeČARIĆ, History, variations and generalisations of the Čebyšev inequality and the question of some priorities II, Rad JAZU (Zagreb), 450, 9 (1990), 139-156.

[9] A. I. STEPANeTS AND A. L. Shidlich, Best approximations of integrals by integrals of finite rank, J. Approx. Theory, 162 (2010), 323-348.

[10] A. I. STEPANETS AND A. L. SHIDliCh, Extremal problems for integrals of nonnegative functions, in Russian, Nats. Akad. Nauk Ukrain., Inst. Mat. Preprint 2007, no. 3, 112 pp.

[11] J. F. StefFensen, En Ulighted mellem Middelve edier, Mat. Tidsskrift, 1920 B, 49-53.

[12] M. BIERNACKI, Sur le 2 theoreme de la moyenne et sur l'integralite de Tschebycheff, Ann. Univ. Mariae Curie-Sklodowska, A4 (1950), 123-129.

[13] A. L. SHIDLICH, Best n-term approximations by $\Lambda$-methods in the spaces $S_{\varphi}^{p}$, in: Extremal Problems in the Theory of Functions (in Ukrainian), Institute of Mathematics, Ukrainian Academy of Sciences, Kyiv (2003), 283-306.

[14] A. I. StePanets And A. L. Shidlich, Best n-term approximations by $\Lambda$-methods in the spaces $S_{\varphi}^{p}$, Ukr. Mat. Zh., 55, 8 (2003), 1107-1126. 